\title{
Pengaruh Harga dan Promosi Terhadap Keputusan Pembelian Helm Merek GM Pada Mahasiswa/i Sekolah Tinggi Ilmu Ekonomi Haji Agus Salim Bukittinggi
}

\author{
${ }^{1}$ Hariman Syaleh \& ${ }^{2}$ Rohimah Nur Nasution \\ ${ }^{1}$ Sekolah Tinggi Ilmu Ekonomi Haji Agus Salim Bukittinggi \\ ${ }^{2}$ AKPAR Paramitha Bukittinggi \\ Email : harimansyaleh@yahoo.co.id
}

\begin{abstract}
This research is motivated by many types and brands of helmets offered to consumers in the market. So that each helmet company must create a strategy to maintain and achieve a higher market share. The problem in this study is "How is the influence of price, quality and promotion of the decision to purchase GM brand helmets for STIE HAS Bukittinggi students. The data used are primary and secondary data. The research data was obtained through questionnaires to 68 respondents. The variables used were dependent variables, namely purchasing decision (Y) and independent variables namely price (X1), and promotion (X2). The method of analysis used by the writer in this research is multiple linear regression analysis. The results of multiple linear regression analysis obtained the following equation: $\mathrm{Y}=15,070+0,222 \mathrm{X} 1+0.782 \mathrm{X} 2$ obtained that prices and promotions have a positive effect on purchasing decisions. The results of the $t$ test and $f$ test are partially and simultaneously have a significant effect on purchasing decisions.
\end{abstract}

Keywords: price, promotion, purchase decision.

\section{Pendahuluan}

Dengan adanya peraturan kepolisian yang mewajibkan penggunan helm standar pada tahun 2003, maka seluruh helm yang tidak lulus persyaratan SNI ( Standar Nasional Indonesia) tidak boleh digunakan. Seiring dengan berjalannya waktu dan diterapkan peraturan ini, maka sekarang ini banyak sekali terdapat merk-merk helm yang ditawarkan kepada konsumen seperti NKH, BMC, KYT, CABERG dan merk helm GM. Dimana masing - masing merk berusaha untuk membuat produknya lebih unggul dibandingkan dengan merk lain. Maka kegiatan pemasaran yang baik dan tepatlah yang memegang peranan yang penting dalam menunjang kelangsungan usaha dan perkembangan suatu perusahaan. Dengan kata lain, pihak produsen harus mampu merebut hati konsumen agar berminat melakukan pembelian terhadap produk yang dijual dan berupaya untuk memuaskan kebutuhan konsumennya.

Dalam memahami prilaku konsumen tentu tidak mudah karena konsumen mempunyai prilaku yang berbeda-beda sesuai dengan kodrat sebagai manusia yang mempunyai kebutuhan tidak terbatas disamping dipengaruhi oleh kondisi eksternal dan internal lainnya yang berakibat langsung terhadap prilaku konsumen. Faktor eksternal yang dimaksud meliputi kebudayaan, sub budaya, kelas social, kelompok social, kelompok referensi, dan keluarga. Sedangkan factor internal adalah factor yang ada pada diri konsumen itu sendiri (psikologis) yang meliputi: belajar, kepribadian, dan konsep diri, serta sikap (Stanton,1996). Oleh sebab itu produsen harus dapat mengendalikan perubahan perilaku konsumen tersebut dengan berusaha

Published by:

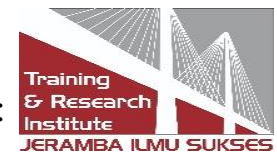


mengimbanginya, yakni dengan mempengaruhi konsumen dalam membeli produk yang ditawarkan dan melalui evaluasi berkala demi kelangsungan hidup produsen itu sendiri.

Demikian juga halnya dengan produk helm, dimana para produsen helm harus memperhatikan prilaku konsumennya, agar minat beli terhadap produk helm tersebut harus ditingkatkan lagi, terutama bagi konsumen dengan kelompok umur remaja. Dari pengamatan yang penulis lakukan pada kelompok remaja dalam hal ini, mahasiswa yang kuliah di STIE Haji Agus Salim Bukittinggi mereka memilih menggunakan helm yang mereknya lebih unggul dan lebih banyak diminati seiring dengan munculnya iklan di televisi.

Keputusan pembelian merupakan suatu keputusan sebagai pemilikan suatu tindakan dari dua atau lebih pilihan alternatif (Sumarwan, 2003). Setiap orang pasti pernah mempertimbangkan sesuatu hal sebelum melakukan keputusan pembelian. Sebelum membeli, konsumen terlebih dahulu akan melakukan beberapa alternatif pilihan, apakah akan membeli atau tidak. Jika konsumen kemudian memutuskan salah satunya, maka konsumen sudah melakukan keputusannya (Sumarwan, 2003). Indikator-indikator seperti produk, harga dan promosi telah terbukti berpengaruh terhadap keputusan pembelian. Hal itu diperkuat dengan adanya penelitian-penelitian dari. Tedjakusuma (2001), Abubakar (2005), Nabhan dan Kresnaini (2005), Satmoko (2005) serta Wijayanti (2008)yang menyatakan bahwa produk, harga dan promosi berpengaruh terhadap keputusan pembelian.

Proses pengambilan keputusan konsumen adalah tahap demi tahap yang digunakan oleh konsumen ketika membeli barang atau jasa (Koesoemaningsi, 2013). Jadi keputusan pembelian adalah suatu keputusan karena ketertarikan yang dirasakan oleh seseorang terhadap suatu produk, dan ingin membeli, mencoba, menggunakan, atau memiliki produk tersebut. Dalam keputusan membeli barang, konsumen sering kali ada lebih dari dua pihak yang terlibat dalam proses pertukaran atau pembeliannya. Setiap produsen pasti menjalankan berbagai strategi agar konsumen memutuskan untuk membeli produknya.

Keputusan pembelian adalah tindakan dari konsumen untuk mau membeli atau tidak terhadap produk (Koesoemaningsi, 2013). Perilaku pembelian konsumen dipengaruhi oleh karakteristik budaya, sosial, pribadi, dan psikologi (Supriyanti, 2012). Faktor budaya, memiliki pengaruh terluas dan terdalam dalam perilakukonsumen. Karena, setiap kelompok atau masyarakat memiliki budaya dan pengaruh budaya pada perilaku konsumen sangat beragam dari satu negara ke negara yang lain. Perilaku konsumen juga dipengaruhi oleh faktor sosial seperti kelompok kecil, keluarga, peran dan status yang melingkupi konsumen tersebut. Kelompok, adalah dua atau lebih sekelompok orang yang berinteraksi untuk memenuhi tujuan individu atau tujuan bersama. Keputusan seorang pembeli juga dipengaruhi oleh karakteristikpribadi seperti umur dan tahapan siklus hidup, pekerjaan, situasi ekonomi, gaya hidup, kepribadian dan konsep diri. Faktor psikologis merupakan hal -hal yang ada dalam diri individu meliputi:

Motivasi, didefinisikan sebagai kesediaan untukmengeluarkan tingkat upaya yang tinggi kearah tujuan -tujuan yang hendak dicapainya, yang dikondisikan oleh kemampuan upaya untuk memenuhi suatu kebutuhan individual (Supriyanti, 2012). Motivasi terbentuk karena adanya stimulus atau rangsangan yang akan menyebabkan pengenalan kebutuhan (need recognition). Pengenalan kebutuhan akan enyebabkan tekanan kepada konsumen sehingga adanya dorongan pada dirinya. Teori kebutuhan Maslow mengemukakan lima kebutuhan manusia sebagai berikut: kebutuhan fisiologis, kebutuhan rasa aman, kebutuhan sosial, kebutuhan ego, kebutuhan aktualisasi diri (Hidayat \& Taufiq, 2012). Berdasarkan latar belakang masalah di

Published by:

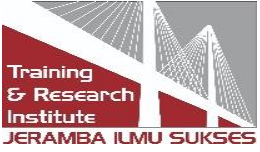


atas maka dirumuskan masalah penelitian ini sebagai berikut : Bagaimana pengaruh harga dan promosi terhadap keputusan pembelian helm merek GM pada mahasiswa STIE Haji Agus Salim Bukittinggi?.

\section{Tinjauan Literatur}

Pengambilan keputusan sebagai proses penting yang mempengaruhi perilaku konsumen dan perilaku konsumen juga sangat penting untuk dipahami oleh pemasar. Perilaku konsumen merupakan studi yang mengkaji bagaimana individu membuat keputusan membelanjakan sumber daya yang dimiliki dan tersedia (waktu, uang dan usaha) untuk mendapatkan barang atau jasa yang nantinya akan dikonsumsi. (Suryani, 2013).

Menurut Kotler (2000), keputusan konsumen dalam pembelian dipengaruhi oleh karakteristik konsumen dan rangsangan pemasaran (marketing stimuli) yang terdiri dari :

a. Produk (Product), yaitu produk apa yang secara tepat diminati oleh konsumen, baik kualitas maupun kuantitasnya.

b. Harga (Price), yaitu seberapa besar harga sebagai pengorbanan konsumen dalam memperoleh manfaat produk yang diinginkan.

c. Distribusi (Place), yaitu bagaimana pendistribusian barang sehingga produk dapat sampai ketangan konsumen dengan mudah.

d. Promosi (Promotion), yaitu pesan-pesan yang dikomunikasikan sehingga keunggulan produk dapat disampaikan kepada konsumen.

Peran Dalam Keputusan Pembelian. Menurut Kotler (2000), seseorang memainkan sebuah peran dalam mengambil keputusan pembelian. Sebuah keputusan pembelian melibatkan seseorang atau beberapa orang. Untuk itu dapat dibedakan beberapa peran yang dimainkan orang dalam suatu keputusan pembelian, yaitu:

1. Pemrakarsa, adalah orang pertama yang menyarankan atau mencetuskan gagasan membeli produk atau jasa tertentu.

2. Pemberi pengaruh: individu yang mempengaruhi keputusan untuk membeli, baik secara sengaja maupun tidak sengaja.

3. Pengambil keputusan: orang yang akhirnya membuat keputusan membeli atau sebagian dari itu, apakah akan membeli, apa yang dibeli, bagaimana membelinya, atau dimana membelinya.

4. Pembeli: orang yang benar -benar melakukan pembelian.

5. Pengguna: orang yang mengkonsumsi atau menggunakan produk atau jasa.

Suatu perusahaan perlu mengenal dan memahami mengenai peran-peran tersebut, karena peran tersebut berguna untuk membantu pemasar dalam menyesuaikan program pemasaran. Selain dipengaruhi oleh karakteristik budaya, sosial, pribadi, dan psikologi keputusan pembelian juga di pengaruhi oleh bauran pemasaran. Menurut Munadi, Ekonomi, \& Gunadarma (2008) bauran pemasaran merupakan alat bagi pemasar yang terdiri dari berbagai unsur suatu program pemasaran yang perlu dipertimbangkan agar implementasi strategi pemasaran dan positioning yang ditetapkan dapat berjalan sukses. Kotler (2000) mengatakan bahwa bauran pemasaran adalah sekumpulan alat pemasaran (bauran pemasaran) yang digunakan oleh perusahaan untuk mencapai tujuan pemasarannya dalam pasar sasaran.

Harga, Haryanto (2013) mendefinisikan harga dari dua sudut pandang, yaitu dari sudut pandang pemasaran, harga merupakan satuan moneter atau ukuran lainnya (termasuk barang dan jasa

Published by:

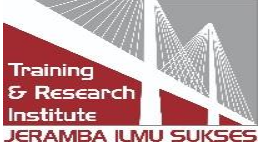


lainnya) yang ditukarkan agar memperoleh hak kepemilikan atau penggunaan suatu barang atau jasa. Harga merupakan variabel yang dapat dikendalikan dan yang menentukan diterima atau tidaknya suatu produk oleh konsumen. Harga tergantung pada kebijakan perusahaan dan harus memonitor harga barang, ditetapkan oleh para pesaing agar harga yang ditetapkan perusahaan tersebut tidak terlalu tinggi atau sebaliknya. Harga adalah nilai suatu barang yang dinyatakan dalam satuan uang. Dalam merumuskan strategi penentuan harga diperhatikan tujuan dari penentuan harga itu sendiri, antara lain Bertahan, memaksimalkan laba, memaksimalkan penjualan, prestige, pengembalian atas investasi.

Keinginan untuk membeli timbul setelah konsumen merasa tertarik dan ingin memakai produk yang dilihatnya, menurut Howard dan Shay (dalam Basu Swastha Dharmmesta, 1998) proses membeli (buying intention) akan melalui lima tahapan, yaitu:

1. Pemenuhan kebutuhan (need)

2. Pemahaman kebutuhan (recognition)

3. Proses mencari barang (search)

4. Proses evaluasi (evaluation)

5. Pengambilan keputusan pembelian (decision)

Menurut William J. Stanton (1994), harga adalah sejumlah nilai yang ditukarkan konsumen dengan manfaat dari memiliki atau menggunakan produk atau jasa yang lainnya ditetapkan oleh pembeli atau penjual untuk satu harga yang sama terhadap semua pembeli. Sedangkan definisi harga oleh Stanton seperti yang dikutip oleh Basu Swastha dan Irawan (1990) adalah sejumlah uang (ditambah beberapa produk kalau mungkin) yang dibutuhkan untuk mendapat-kan sejumlah kombinasi dari produk dan pelayanan.

Promosi, menurut Mandey (2013) promosi adalah sejenis komunikasi yang memberikan penjelasan yang meyakinkan calon konsumen tentang barang dan jasa. Pengertian promosi menurut Suharno dan Sutarso (2010) adalah aktivitas komunikasi pemasaran untuk mempengaruhi pasar sasaran agar membeli produk yang dipasarkan.

Promosi merupakan salah satu faktor penentu keberhasilan suatu program pemasaran. Betapapun berkualitasnya produk, bila konsumen belum pernah mendengarnya dan tidak yakin bahwa produk itu akan berguna bagi mereka, maka mereka tidak akan pernah membelinya. Pada dasarnya promosi bertujuan agar volume penjualan dapat dinaikkan dengan berusaha mempengaruhi keputusan konsumen untuk memilih dan membeli produk yang ditawarkan. Secara luas dikatakan bahwa promosi merupakan bagian dari proses komunikasi pemasaran, sebagai arus informasi atau persuasive satu arah yang dilakukan satu organisasi atau individu tertentu. Ada beberapa cara dalam menyebarkan informasi yaitu melalui iklan, publisitas, promosi penjualan, public relations, personal selling dan direct marketing.

Berdasarkan latar belakang masalah yang dikemukakan maka ditarik hipotesis yaitu diduga:

$\mathrm{H}_{1}$ : Harga berpengaruh signifikan terhadap keputusan pembelian

$\mathrm{H}_{2}$ : Promosi berpengaruh signifikan terhadap keputusan pembelian

$\mathrm{H}_{3}$ : Harga, dan Promosi berpengaruh signifikan terhadap keputusan pembelian 


\section{Metode Penelitian}

Dalam suatu penelitian ilmiah metode pengumpulan data dimaksudkan untuk memperoleh bahan-bahan yang relevan, akurat, dan terpercaya (Supranto, 1996). Teknik pengumpulan data yang digunakan peneliti dalam penelitian ini adalah survei melalui kuesioner. Kuesioner merupakan teknik pengumpulan data yang dilakukan dengan cara memberi seperangkat pertanyaan atau pertanyaan tertulis kepada responden untuk dijawabnya (Sugiyono, 2008).

Metode pengumpulan data yang dilakukan dengan cara memberikan pertanyaan-pertanyaan kepada responden dengan panduan kuesioner. Dalam penelitian ini kuesioner menggunakan pertanyaan tertutup dan terbuka. Pengumpulan data yang dilakukan dengan membaca bukubuku literatur, jurnal-jurnal, internet, majalah dan penelitian terdahulu yang berkaitan dengan penelitian yang sedang dilakukan.

Populasi pada penelitian ini adalah konsumen yang melakukan pembelian mobil Toyota pada PT. Intercom Mobilindo Padang sebanyak 212 orang. Sampel merupakan bagian yang diambil dari populasi, Dalam penelitian ini yang menjadi populasi adalah mahasiswa/i STIE HAS reguler pagi yang terdiri dari Bp 14, 15, 16 dan 17, yang berjumlah 212 orang, seperti terlihat pada tabel berikut :

Tabel 1. Jumlah Data Mahasiswa/i STIE HAS Pagi Tahun 2016-2019

\begin{tabular}{|l|l|l|l|l|l|}
\hline Bp & $\mathbf{2 0 1 6}$ & $\mathbf{2 0 1 7}$ & $\mathbf{2 0 1 8}$ & $\mathbf{2 0 1 9}$ & Total \\
\hline Jumlah & 88 & 31 & 45 & 48 & 212 \\
\hline
\end{tabular}

Sumber : STIE HAS Bukittinggi, 2020

Jumlah populasi yang ada maka diambil sebagian sampel untuk mewakili keseluruhan populasi. Sampel yang digunakan sebanyak 68 orang, dengan tingkat kesalahan pengambilan sampel 10 persen.

Pada program Statistical Product and Service Solution (SPSS) teknik pengujian yang digunakan korelasi Corrected Item-Total Corelation. Uji dalam penelitian ini untuk mengetahui valid suatu variabel dilakukan pengujian dengan menggunakan teknik validity analysis dengan nilai korelasi diatas 0,3 (Sekaran; 2000). Untuk menguji apakah alat ukur (instrument) yang digunakan memenuhi syarat -syarat alat ukur yang baik, sehingga menghasilkan data yang sesuai dengan apa yang diukur, terlebih dahulu dilakukan pengujian data melalui uji validitas dan reliabilitas data. Pengujian ini dilakukan sebelum data dianalisis lebih lanjut.

Uji reliabilitas digunakan untuk mengetahui sejauh mana pengukuran itu memberikan hasil relatif tidak berbeda apabila dilakukan pengukuran ulang pada subyek yang sama. Reliabilitas menunjukkan konsistensi dan stabilitas dari skor (skala pengukuran). Kriteria yang digunakan untuk mengetahui tingkat reliabilitas adalah besarnya nilai cronbach's alpha. Instrumen penelitian disebut handal apabila hasil pengujian menunjukkan alpha lebih besar dari 0,6 (Sugiyono, 2006).

Teknik analisis data menggunakan statistik deskriptif antara lain adalah penyajian data melalui tabel, grafik, diagram lingkaran, pictogram, perhitungan modus, median, mean (pengukuran tendensi sentral), perhitungan desil, persentil, perhitungan penyebaran data melalui perhitungan rata-rata dan standar deviasi, dan perhitungan persentase. Model regresi linier berganda dapat disebut model yang baik jika model tersebut memenuhi Kriteria BLUE (Best Linier Unbiased

Published by:

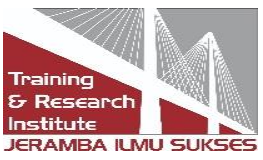


Estimator). BLUE dapat dicapai apabila memenuhi Asumsi Klasik. Uji asumsi klasik mencakup : uji multikolinieritas, uji heteroskedastisitas dan uji normalitas.

Analisis regresi linier berganda adalah hubungan secara linear antara dua atau lebih variabel independen $(\mathrm{X} 1, \mathrm{X} 2, \ldots . \mathrm{Xn})$ dengan variabel dependen $(\mathrm{Y})$. Analisis ini untuk mengetahui arah hubungan antara variabel independen dengan variabel dependen apakah masing -masing variabel independen berhubungan positif atau negatif dan untuk memprediksi nilai dari variabel dependen apabila nilai variabel independen mengalami kenaikan atau penurunan.

Data dianalisis menggunakan beberapa prosedur diantaranya, uji validitas, uji reliabilitas dan uji asumsi klasik yang terdiri dari: uji normalitas, uji heterokedasitas, dan uji multikolinieritas.

Ada dua bentuk hipotesis yang digunakan yaitu :

Ho : Tidak ada hubungan antara faktor psikologis dan bauran pemasaran dengan keputusan beli kensumen.

Ha : Terdapat hubungan antara faktor psikologis dan bauran pemasaran dengan keputusan pembelian.

Ho dan Ha cenderung bertolak belakang

Ho $><$ Ha, Ho cenderung ditolak Ha cenderung diterima.

Adapun dasar kriteria pengambilan keputusannya yaitu melalui angka probabilitas signifikan sebagai berikut:

Jika probabilitas F > 0.05 maka Ho diterima dan Ha ditolak.

Jika probabilitas $\mathrm{F}<0.05$ maka Ho ditolak dan Ha diterima

\section{Hasil Dan Pembahasan}

\subsection{Hasil Uji Validitas Variabel Keputusan Pembelian ( $Y$ )}

Kuesioner penelitian variable keputusan pembelian (Y) terdiri atas sepuluh item Pertanyaan. Hasil pengujian untuk masing -masing indicator keputusan pembelian dapat dilihat dalam tabel berikut.

Tabel 2. Hasil Uji Validitas Variabel Keputusan Pembelian (Y)

\begin{tabular}{|l|c|c|c|}
\hline No Item Pernyataan & Nilai r Hitung & Nilai r Kritis & Keterangan \\
\hline K. Pembelian 1 & 0.602 & 0.300 & Valid \\
\hline K. Pembelian 2 & 0.521 & 0.300 & Valid \\
\hline K. Pembelian 3 & 0.491 & 0.300 & Valid \\
\hline K. Pembelian 4 & 0.435 & 0.300 & Valid \\
\hline K. Pembelian 5 & 0.474 & 0.300 & Valid \\
\hline K. Pembelian 6 & 0.811 & 0.300 & Valid \\
\hline K. Pembelian 7 & 0.654 & 0.300 & Valid \\
\hline K. Pembelian 8 & 0.571 & 0.300 & Valid \\
\hline K. Pembelian 9 & 0.654 & 0.300 & Valid \\
\hline K. Pembelian 10 & 0.435 & 0.300 & Valid \\
\hline
\end{tabular}

Sumber : Hasil Pengolahan data Primer Tahun 2020

Published by:

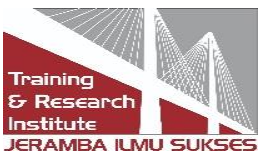


Berdasarkan Tabel 2 di atas, pengujian validitas dimulai dari uji validitas variabel Keputusan pembelian (Y) dari 10 butir pertanyaan yang ada, ditemukan semua item Pernyataan valid untuk keputusan pembelian. Dari hasil uji validitas diperoleh semua nilai korelasi masing-masing lebih besar dari nilai korelasi kritis atau 0.30. Dengan demikian semua item Pernyataan variabel Keputusan pembelian (Y) dapat digunakan untuk pengujian lebih lanjut.

\subsection{Hasil Uji Validitas Variabel Harga (X1)}

Hasil Uji Validitas Variabel Harga (X1) Kuesioner penelitian variabel harga (X1) terdiri atas empat item. Hasil pengujian masing-masing indikator harga 1 sampai dengan harga 5 menunjukkan bahwa terdapat 1 item pertanyaan yang tidak valid, yaitu item pertanyaan 2 . Karena item pertanyaan tersebut memiliki nilai Correlated Item -Total Correlation yang lebih kecil dari 0.300. Sehingga item pertanyaan tersebut tidak bisa dipakai untuk mengukur variabel yang diteliti. Hasil pengujian validitas variable harga (X1) dapat dilihat dalam tabel berikut :

Tabel 3. Hasil Uji Validitas Variabel Harga (X1)

\begin{tabular}{|l|c|c|c|}
\hline No Item Pernyataan & Nilai r Hitung & Nilai r Kritis & Keterangan \\
\hline Harga 1 & 0.794 & 0.300 & Valid \\
\hline Harga 2 & 0.683 & 0.300 & Valid \\
\hline Harga 3 & 0.532 & 0.300 & Valid \\
\hline Harga 4 & 0.360 & 0.300 & Valid \\
\hline Harga 5 & 0.839 & 0.300 & Valid \\
\hline Harga 6 & 0.565 & 0.300 & Valid \\
\hline Harga 7 & 0.711 & 0.300 & Valid \\
\hline Harga 8 & 0.445 & 0.300 & Valid \\
\hline
\end{tabular}

Sumber : Hasil Pengolahan data Primer Tahun 2020

Dari Tabel 3 di atas, hasil pengujian validitas untuk variabel harga (X1), ditemukan semua item pernyataan yang terdiri dari 8 item pernyataan dinyatakan valid, karena nilai validitas harga memiliki nilai $r$ diatas 0.300 oleh karena itu item-item yang telah valid dapat digunakan untuk pengujian lebih lanjut.

\subsection{Hasil Uji Validitas Variabel Promosi (X2)}

Selanjutnya berikut ini adalah hasil pengujian validitas untuk item Pernyataan pada variabel promosi (X2), akan disajikan pada Tabel 4. berikut ini:

Tabel 4. Hasil Uji Validitas Variabel Promosi (X2)

\begin{tabular}{|l|c|c|c|}
\hline No Item Pernyataan & Nilai r Hitung & Nilai r Kritis & Keterangan \\
\hline Promosi 1 & 0.574 & 0.300 & Valid \\
\hline Promosi 2 & 0.574 & 0.300 & Valid \\
\hline Promosi 3 & 0.726 & 0.300 & Valid \\
\hline Promosi 4 & 0.559 & 0.300 & Valid \\
\hline Promosi 5 & 0.792 & 0.300 & Valid \\
\hline Promosi 6 & 0.383 & 0.300 & Valid \\
\hline Promosi 7 & 0.759 & 0.300 & Valid \\
\hline Promosi 8 & 0.467 & 0.300 & Valid \\
\hline Promosi 9 & 0.616 & 0.300 & Valid \\
\hline Promosi 10 & 0.670 & 0.300 & Valid \\
\hline
\end{tabular}

Published by:

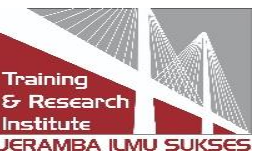


Sumber : Hasil Pengolahan data Primer Tahun 2020

Berdasarkan Tabel 4. di atas, pengujian validitas dimulai dari uji validitas variabel promosi (X2) dari 10 butir pertanyaan yang ada dinyatakan semuanya valid, karena diperoleh semua nilai korelasi masing-masing lebih besar dari nilai korelasi kritis atau 0.30. Dengan demikian semua item Pernyataan variabel promosi (X2) dapat digunakan untuk pengujian lebih lanjut.

\subsection{Uji Reliabilitas}

Uji reliabilitas adalah suatu uji yang menunjukkan sejauh mana pengukuran itu dapat memberikan hasil yang relatif tidak beda dilakukan pengulangan pengukuran terhadap subjek yang sama. Uji ini hanya dapat dilakukan pada pertanyaan-pertanyaan yang valid saja. Pengujian reliabilitas dilakukan dengan menggunakan rumus alpha atau Cronbach's Alpha, instrumen yang mempunyai reliabilitasi. Instrumen yang dipakai dalam variabel itu dikatakan handal apabila memiliki cronbach's alpha lebih dari 0,60 (Ghozali, 2005). Hasil analisis reliabilitas terhadap masing-masing instrumen penelitian diketahui bahwa nilai Koefisien Alpha Cronbach dari masing-masing variabel dapat dilihat pada Tabel 5 berikut ini:

Tabel 5. Hasil Uji Reliabilitas Variabel Penelitian

\begin{tabular}{|c|l|c|c|c|}
\hline No & \multicolumn{1}{|c|}{ Variabel } & $\begin{array}{c}\text { Jumlah } \\
\text { Item }\end{array}$ & $\begin{array}{c}\text { Alpha } \\
\text { Cronbach }\end{array}$ & Keterangan \\
\hline 1 & Keputusan pembelian (Y) & 10 & 0,849 & Reliabel \\
\hline 2 & Harga (X1) & 8 & 0,854 & Reliabel \\
\hline 3 & Promosi (X2) & 10 & 0,874 & Reliabel \\
\hline
\end{tabular}

Sumber : Hasil Pengolahan data Primer Tahun 2020

Berdasarkan Tabel 5, hasil pengolahan data untuk uji reliabilitas variabel penelitian sebagaimana yang terlihat pada tabel di atas terlihat bahwa semua variabel memiliki angka alpha cronbach lebih besar dari 0,6. Hal ini menandakan bahwa semua variabel penelitian memiliki kuesioner yang handal atau reliabel.

\subsection{Analisis Regresi Berganda}

Penelitian ini merupakan studi empiris (empirical study) yaitu studi tentang fakta / data nyata yang dikumpulkan dan diuji secara sistematis. Regresi linear berganda, yaitu suatu metode statistik yang digunakan untuk mengetahui hubungan antara satu variabel terikat (dependent variabel) dengan dua atau lebih variabel (independent variabel) dan hubungan antara variabel terikat (keputusan pembelian) dengan variabel bebas (harga, dan promosi), ditunjukkan oleh rumus sebagai berikut (Djarwanto, 2001). Untuk mengetahui apakah terdapat pengaruh secara parsial (individu) dari variable-variabel independen (harga, dan promosi) terhadap variable dependen yaitu keputusan pembelian, maka dilakukan pengujian secara statistik dengan melakukan uji t. Pengaruh variable independen terhadap dependen tersebut dapat diketahui setelah melakukan estimasi dengan menggunakan model regresi berganda (multiple regression analysis). Hasil estimasi model tersebut terlihat pada tabel berikut : 
Tabel 6. Hasil Analisa Regresi Linear Berganda

\begin{tabular}{|l|l|c|c|}
\hline Variabel Terikat & \multicolumn{1}{|c|}{$\begin{array}{c}\text { Konstanta dan Variabel } \\
\text { Bebas }\end{array}$} & $\begin{array}{c}\text { Koefisien } \\
\text { Regresi }\end{array}$ & Signifikan \\
\hline \multirow{2}{*}{$\begin{array}{l}\text { Kepuasan Kerja } \\
\text { (Y) }\end{array}$} & Konstanta (a) & 15,070 & 0,000 \\
\cline { 2 - 4 } & Harga (X1) & 0,222 & 0.026 \\
\cline { 2 - 4 } & Promosi (X2) & 0,782 & 0,000 \\
\cline { 2 - 4 } & F & 51,623 & 0,000 \\
\cline { 2 - 4 } & $\mathrm{R}^{2}$ & \multicolumn{2}{|c|}{0,781} \\
\hline
\end{tabular}

Sumber: Hasil Pengolahan Data Primer, 2020

Berdasarkan Tabel 6 terlihat bahwa nilai konstantanya sebesar 15,070 dan nilai koefisien regresi untuk masing-masing variabel bebas menyatakan bahwa nilai koefisien regresi harga (X1) adalah 0,222 dengan tingkat signifikansi sebesar 0,026. Nilai signifikansi tersebut lebih kecil dari 0,05. Dengan demikian, dapat diartikan bahwa variabel harga berpengaruh positif dan signifikan terhadap keputusan pembelian helm merek GM pada mahasiswa STIE Haji Agus Salim Bukittinggi (Y). Oleh karena itu hipotesis $\mathrm{H} 1$ penelitian ini yang menyatakan bahwa harga berpengaruh positif dan signifikan terhadap keputusan pembelian helm merek GM pada mahasiswa STIE Haji Agus Salim Bukittinggi” diterima.

Koefisien regresi promosi (X2) adalah 0,782 dengan tingkat signifikansi sebesar 0,000. Nilai signifikansi tersebut lebih kecil dari 0,05. Dengan demikian, dapat diartikan bahwa variabel promosi berpengaruh positif dan signifikan terhadap keputusan pembelian helm merek GM pada mahasiswa STIE Haji Agus Salim Bukittinggi (Y). Oleh karena itu hipotesis H2 penelitian ini yang menyatakan bahwa promosi berpengaruh signifikan terhadap keputusan pembelian helm merek GM pada mahasiswa STIE Haji Agus Salim Bukittinggi” diterima.

Selanjutnya nilai koefisien regresi harga (X1) dan promosi (X2) secara bersama - sama adalah 51,623 dengan tingkat signifikansi sebesar 0,000. Nilai signifikansi tersebut lebih kecil dari 0,05. Dengan demikian, dapat diartikan bahwa variable harga dan promosi secara bersama sama berpengaruh signifikan terhadap keputusan pembelian helm merek GM pada mahasiswa STIE Haji Agus Salim Bukittinggi (Y) oleh karena itu hipotesis H3 penelitian ini yang menyatakan bahwa harga dan promosi berpengaruh signifikan terhadap keputusan pembelian helm merek GM pada mahasiswa STIE Haji Agus Salim Bukittinggi dapat diterima.

Nilai $\mathrm{R}^{2}$ ( $R$ square) adalah sebesar 0,781 yang berarti bahwa kontribusi atau penjelasan dari variable harga dan promosi terhadap keputusan pembelian helm merek GM pada mahasiswa STIE Haji Agus Salim Bukittinggi adalah $78 \%$, dimana sisanya sebesar $22 \%$ dipengaruhi oleh variabel-variabel lain yang tidak termasuk dalam model penelitian ini.

\section{Kesimpulan}

Dari hasil uji instrument penelitian menunjukkan bahwa kedua variabel ketiga variabel yang penulis teliti menunjukkan keriteria yang shahih valid dan handal, karena nilai Correlated Item -Total Correlation atau $r$ hitung lebih besar dari $r$ tabel sehingga semua item pernyataan dapat digunakan untuk penelitian selanjutnya. Begitu juga dengan tingkat reliabilitas yang ada menunjukkan keriteria reliabel karena nilai Alpha Cronbach lebih besar dari 0,6 sehingga dapat dilakukan pengujian selanjutnya.

Published by:

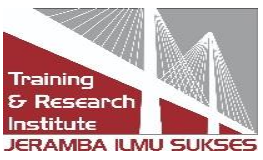


Berdasarkan Tabel 6 di atas, diketahui hasil pengujian data dengan analisis regresi linear berganda nilai konstanta sebesar 15,070 yang artinya keputusan pembelian helm merek GM pada mahasiswa STIE Haji Agus Salim Bukittinggi sudah ada sebelum dipengaruhi variable lain. Harga (X1) berpengaruh positif dan signifikan terhadap keputusan pembelian helm merek GM pada mahasiswa STIE Haji Agus Salim Bukittinggi, apabila harga di tingkatkan satu satuan maka keputusan pembelian helm merek GM pada mahasiswa STIE Haji Agus Salim Bukittinggi akan meningkat sebesar 0,222, begitu juga dengan variable promosi apabila di tingkatkan satu satuan maka keputusan pembelian helm merek GM pada mahasiswa STIE Haji Agus Salim Bukittinggi akan meningkat sebesar 0,782 dengan asumsi variable lain tetap.

Berdasarkan hasil pengujian hipotesis pertama, kedua dan ketiga di atas, ditemukan bahwa harga dan promosi berpengaruh positif dan signifikan terhadap keputusan pembelian helm merek GM pada mahasiswa STIE Haji Agus Salim Bukittinggi. Dalam artian semakin baik harga dan promosi yang diterapkan perusahaan, maka akan meningkatkan keputusan pembelian helm merek GM pada mahasiswa STIE Haji Agus Salim Bukittinggi. Temuan ini menunjukan bahwa harga dan promosi adalah faktor yang menentukan tingkat keputusan pembelian helm merek GM pada mahasiswa STIE Haji Agus Salim Bukittinggi.

Berdasarkan hasil pengujian hipotesis dan temuan yang ada tentang "Pengaruh harga dan promosi Terhadap Keputusan pembelian helm merek GM pada mahasiswa STIE Haji Agus Salim Bukittinggi, dapat disimpulkan bahwa hipotesis pertama, kedua dan ketiga secara empiris ditemukan pengaruh yang positif dan signifikan antara harga dan promosi terhadap keputusan pembelian helm merek GM pada mahasiswa STIE Haji Agus Salim Bukittinggi. Temuan ini menunjukan bahwa harga dan promosi yang ada signifikan baik secara parsial maupun secara simultan atau bersama-sama. Keterbatasan penelitian ini adalah jumlah sampel yang sebaiknya mewakili seluruh populasi, saran untuk peneliti selanjutnya adalah agar menambahkan variabel lain diluar variabel yang diteliti oleh penulis dalam penelitian ini

\section{Referensi}

Anwar, S., \& Susanto, R. (2017). Faktor-Faktor Yang Mempengaruhi Keputusan Konsumen Membeli Asuransi Jiwa Ajb Bumiputera 1912, 1(1), 33-44.

Dinawan, M. R., Kunci, K., \& Produk, K. (2010). Analisis Faktor - Faktor Yang Mempengaruhi Keputusan Pembelian (Studi kasus pada konsumen Yamaha Mio PT Harpindo Jaya Semarang). Jurnal Sains Pemasaran Indonesia, 9(3), 335-369.

Doni Marlius. (2017), Keputusan Pembelian Berdasarkan Faktor Psikologis Dan Bauran Pemasaran PT. Intercom Mobilindo Padang, 1(1), 57-66.

Ekstern, F., Jual, F. P., \& Pembelian, K. (2012). Analisis Faktor-Faktor Yang Mempengaruhi Keputusan Pembelian Mobil Toyota Avanza, I (1), 74-90.

Staf, P., \& Akuntan, K. (1999). Analisis faktor-faktor yang mempengaruhi, (914), 1-10.

Sari, A. I. (2013). Faktor - Faktor Yang Mempengaruhi Perilaku Konsumen Dalam Keputusan Pembelian Ponsel Blackberry Pada Mahasiswa Stie Harapan Medan. Jurnal E-Maksi Harapan, 1(1), 35-50.

Verina, E., Yulianto, E., \& Latief, W. A. (2014). Faktor-Faktor Yang Mempengaruhi Keputusan Pembelian Pada Toko Fashion Di Jejaring Sosial Facebook (Survei pada

Published by:

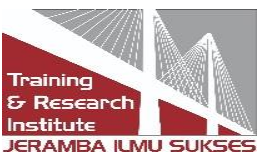


Konsumen Toko Fashion di Jejaring Sosial Facebook yang berlokasi di Indonesia). Jurnal Administrasi Bisnis, 10(1), 1-10.

Wahyuni Putri Kasbella dan Putu Nisa Madiawati. (2017). Analisis Faktor-Faktor Yang Mempengaruhi Keputusan Pembelian Konsumen Terhadap Produk Kosmetik Jafra. EProceeding of Management ISSN: 2355-9357, 4(1), 660-669.

\section{Copyrights}

Copyright for this article is retained by the author(s), with first publication rights granted to the journal.

This is an open-access article distributed under the terms and conditions of the Creative Commons Attribution license (http://creativecommons.org/licenses/by/4.0/) 